\title{
Remembrances of a Conference Past: The NCLA Centennial Conference (1904-2004) and the 2004 SELA Biennial Conference
}

by Plummer Alston Jones, Jr.

T

The North Carolina Library Association (NCLA) Centennial Conference (1904-2004) was held at the Charlotte Convention Center and the Westin Charlotte Hotel on Tuesday-Friday, November 9-12, 2004. The NCLA Centennial was a joint celebration along with the Southeastern Library Association (SELA) Biennial Conference. Pauletta Brown Bracy, NCLA President, and Ann Hamilton, SELA President, shared the honor of hosting this memorable event.

John Via (Forsyth County Public Library) was Conference Chair, with the able assistance of co-chairs Judith Gibbons (SELA Vice President/President Elect) and Mark Pumphrey (Polk County Public Library); NCLA Administrative Assistants, Kim Parrott and Caroline Walters; and SELA Administrative Assistant, Bob Fox. Other Conference Planning Committee members (their institutional affiliations) and areas of planning responsibility included Susan Herzog (Public Library of Charlotte and Mecklenburg County) (PLCMC), Programs; Vanessa Work Ramseur (PLCMC), Local Arrangements; Suzanne White (Rowan Public Library), Publicity and Publications; Steve Kelley (Wake Forest University), Exhibits; Andrea Tullos (Hyconeechee Regional Library System), Registration; Kevin Cherry (East Carolina University) (ECU), Centennial History; Teresa Wehrli (Wake Technical Community College), Conference Store; Candy Ortman (Ingram Library Services), Vendor Representative; Jeanne Crisp (State Library of North Carolina) (SLNC), Member-at-Large; Faith Line (Sumter County (SC) Library), SELA Secretary; Connie Keller (Elon University), NCLA Secretary; Jessica Buehring and Elizabeth Urbanik (Mississippi State University), Poster Sessions; Diane Kester (ECU), Conference Treasurer; Pam Jaskot (SLNC), Swap and Chat; Philip Cherry (Durham County Public Library), Site Selection; and Bao-Chu Chang (North Carolina State University (NCSU) Libraries), Conference Web Site.

What follows is a recapitulation of the conference arranged by sponsoring group. Special thanks are due to unofficial reporters Joline Ezzell (Duke University), Audrey Fenner (University of North Carolina-Greensboro) (UNCG), Annis Barbee (NCSU Libraries), Joan Ferguson (University of North Caorlna-Chapel Hill) (UNC-CH), Jennie Hunt (Greensboro College), and Bryna Coonin (ECU).

Since there was not a professional photographer for the conference, we are beholden to unofficial photographers who shared their photographs. Credits for the photographs go to Diane Kester (ECU), Paula Brown (Gaston 
Lincoln Regional Library), Patrick Valentine (Wilson County Public Library), June Powers (University of North Carolina-Pembroke) (UNCP), Sonia Coffin (Central Piedmont Community College), and Pam Jaskot (SLNC).

A video record was made of the conference by June Powers (UNCP) with the expert filming and editing assistance of John Kincheloe (Meredith College), Denise Bosselman (Sandhills Community College), and Joel White (Forsyth County Public Library). Pamela McCarter and Nicole Pugh (PLCMC) also assisted with the filming. The video is going to be transferred to a DVD that will be available at the NCLA Archives at the State Library of North Carolina and on the NCLA Web Page.

\section{Preconferences (Tuesday, November 9)}

There were seven preconference programs. The NCLA Public Library Section sponsored three concurrent preconferences, 9:00 a.m.-4:00 p.m. in the Westin Charlotte Hotel: "RFID Technology: What's All the Fuss About?," with Phillip Whitford, Braswell Memorial Public Library, Rocky Mount; "Project Management Concepts," with Olaf Baumgartner,

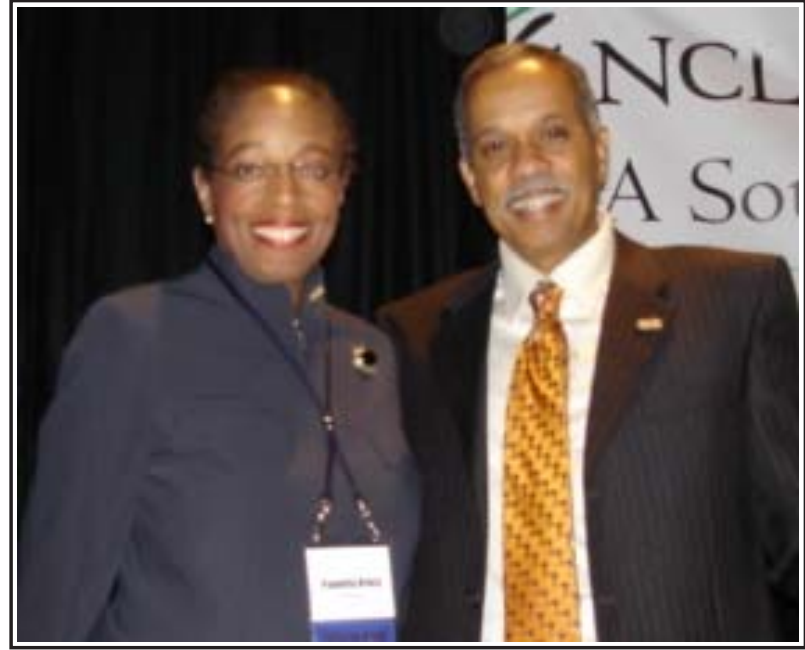

NCLA President Pauletta Bracy with opening session speaker, Juan Williams, senior correspondent for National Public Radio's "Morning Edition." Photo courtesy of Diane Kester. Vice President of Technology at the Project Management Institute, Metrolina Chapter; and "Security in Libraries," with Warren Graham, Security Manager (PLCMC).

SELA sponsored "2004 ACRL Standards: Practical Applications for Academic Libraries," with Bill Nelson (Augusta State University) and Bob Fernekes (Georgia Southern University) which was held 1:00-5:00 p.m. in the Westin. The NCLA Round Table for Ethnic Minority Concerns and the SELA African American Issues Round Table co-sponsored "Where We Need to Be: Librarians Equipped to Meet the 21st Century Leadership Challenge," with Emma Bradford Perry (Georgia Southern University); Tracie Hall (ALA Office for Diversity); and Ron Baza, management consult and leadership development expert, which was held 9:00 a.m.-4:00 p.m. in the PLCMC Auditorium.

The State Library of North Carolina sponsored "Spanish Health Information Resources for English Speaking Librarians," with Becky Hebert (Southeastern Atlantic Region, National Network/Libraries of Medicine), which was held 1:00-4:00 p.m. in PLCMC's Freedom Regional Library Computer Lab.

NCLA, the Open Government Coalition, the North Carolina Press Association, the North Carolina Association of Broadcasters, the Electronic News Association of the Carolinas, and the UNC-CH School of Journalism co-sponsored "Open Government Coalition Workshop" to discuss topics regarding open government, including open meetings, public records, intellectual freedom, obtaining information from the government, and USA PATRIOT Act issues, which was held 9:30 a.m.2:00 p.m. in the Westin.

\section{General Sessions and Special Programs}

On Wednesday, November 10, 2004, 10:00-11:30 a.m., Juan Williams, senior correspondent for National Public Radio's "Morning Edition," addressed the Opening General Session of the NCLAs Centennial Conference and the SELAs Biennial Conference. Williams is the author of the critically acclaimed biography, Thurgood Marshall: American Revolutionary, and the nonfiction bestseller, Eyes on the Prize: America's Civil Rights Years, 1954-1965, the companion volume to the award-winning television series. During his twenty-one-year career at The Washington Post, Williams served as an editorial writer, op-ed columnist, and White House reporter.

On Thursday, November 11, 7:30-8:45 a.m., Keith Fiels, director of the Massachusetts Board of Library Commissioners in Boston since 1992, pre- 
sented a program "Library Budgeting." From noon to 1:30 p.m. on Thursday, NCLA presented its "Presidents' Celebration Luncheon," featuring Robert Martin (Institute of Museum and Library Services) (IMLS). Past NCLA Presidents were recognized. From 2:00-3:30 p.m. on Thursday, the Second General Session "Finding OZ: Discovering a Bright Future for Libraries," was presented by Stephen Abram, president of the Canadian Library Association.

On Friday, November 12, 9:15-10:15 a.m., Carol Brey-Casiano, American Library Association President, addressed the Third General Session of the conference. Brey-Casiano is Director of the El Paso Public Library, which serves nearly one million people in a U.S.-Mexico border community. Also, on Friday, 3:30-5:00 p.m., the Fourth General Session: Conference Dessert Finale featured author James W. Hall, and a video collage of conference activities.

Also, on Friday, 10:30-11:45 a.m., NCLA and SELA co-sponsored "Looking for Librarians in All the Right Places: Recruitment Strategies," with Elizabeth Aversa (University of Alabama); Marcella Genz (Florida State University); Paul Solomon (UNC-CH); and Robert Martin (Institute of Museum and Library Services).

\section{Business Librarianship in North Carolina (BLINC)}

The NCLA BLINC sponsored a program "Market Research Using NC LIVE and Free Web Sources" on Wednesday, November 10, 2:30-3:30 p.m. On Thursday, November 11, 9:30-11:00 a.m., BLINC sponsored "'Granting' Your Wishes: Writing Grant Proposals," with Joanne Kepics (Foundation Center). On Friday, November 12, 10:30-11:45 a.m., BLINC sponsored "Strike It Rich!: Local Libraries as Resources for Economic Development," with Rita W. Moss (UNC-CH); Jeanie Welch (Uuniversity of North Carolina-Charlotte) (UNCC); and Martha Thomas (Greensboro Public Library).

On Friday, November 12, 2:00-3:15 a.m., BLINC sponsored "Creating the One-Stop Business Information Network," with Bonnie Tijerina and Susan Wolf Neilson (NCSU Libraries).

\section{Children's Services Section (CSS)}

The NCLA Children's Services Section sponsored a breakfast meeting on Wednesday, November 10, 2004, 7:30-9:00 a.m., on "Ten Trends in Serving Young Adults," with young adults expert and author Patrick Jones. From 2:30-3:30 p.m., on Wednesday, the CSC sponsored "Library Programs for Babies," with Loretta Talbert (PLCMC North County Regional Library); and Debbie Oldenburg (Hickory Public Library). From 3:45 to 5:00 p.m., the CSC sponsored "A Sampling of North Carolina Children's Writers and Illustrators," with Frances O’Roark Dowell, Jim Young, and Steve Barr.

On Thursday, November 11, 9:30-11:30 a.m., the CSS sponsored "Puppets: Practice and Presentation," with PLCMC staff members. On Friday, November 12, 2:00-3:15 p.m., the CSS sponsored "Storytelling as a Multicultural Bridge," featuring award-winning storytellers and recording artists Donna Washington and Carrie Sue Ayvar.

\section{College and University Section (CUS)}

On Thursday, November 11, 2004, 4:15-5:15 p.m., the NCLA College and University Section and SELA presented "Serials in the Library: Two Pieces of the Puzzle," with Alan May (University of Alabama); and Tim Bucknall (UNC-G). On Friday, November 12, 10:30-11:45 a.m., CUS presented "A Southern View of the History of Academic Library Architecture," with Kathryn Schlee (Old Salem, Inc./Museum of Early Southern Decorative Arts (MESDA)).

\section{Community and Junior College Libraries Section (CJCLC)}

On Wednesday, November 10, 3:45-5:00 p.m., the NCLA CJCLS sponsored "Adapting Retail Strategies for Customer Service: Customer Interface in Your 
Place," featuring Mike Crumpton (Wake Technical Community College).

\section{Exhibits}

Exhibits and the Conference Store were available to conference attendees Wednesday, November 10 - Friday, November 12. Over 100 vendors of library services, resources, and products were available to answer questions and place orders.

\section{Government Resources Section (formerly Documents Section)}

On Friday, November 12, 2004, 10:30-11:45, the NCLA Documents Section presented a panel on "Trends in Documents Collection Development." Panelists included John P. Abbott (Appalachian State University), Mimi Curlee (PLCMC), Frank Molinek (Davidson College), and Marilyn Schuster, and Lois Stickell (both at UNCC).

This informative presentation was followed by the section's business meeting. By unanimous vote, culminating a year-long process, the section's name was changed to Government Resources Section. The slate of new officers was also unanimously accepted. Chair Beth L. Rowe (UNC-CH) will be joined by Vice-Chair/Chair-Elect Beth Kaylor (UNCW) and Secretary/ Treasurer Dianne Ford (Elon University). Some preliminary planning was done for programs for the coming year, including a possible joint offering with BLINC.

\section{Intellectual Freedom Committee}

The NCLA and SELA Intellectual Freedom Committees presented "The Mystery of Full Text Databases: What's Missing?," featuring Camille McCutcheon (SELA Intellectual Freedom Committee), Donald Doak (EBSCO), Carol Richman (SAGE Publications), and Nancy Kopans (JSTOR).

\section{Library Administration and Management Section (LAMS)}

The NCLA Library Administration and Management Section sponsored a luncheon "CIRC Interest Group Table Talk," Wednesday, November 10, 12:30-2:00 p.m. Also, on Wednesday, 3:45-5:00 p.m., LAMS sponsored "The Essentials of a Building Program," with David R. Moore II (Craig, Gaulden, Davis Architects, of Greenville).

On Thursday, November 11, 9:30-11:00 a.m., LAMS sponsored "Manag-

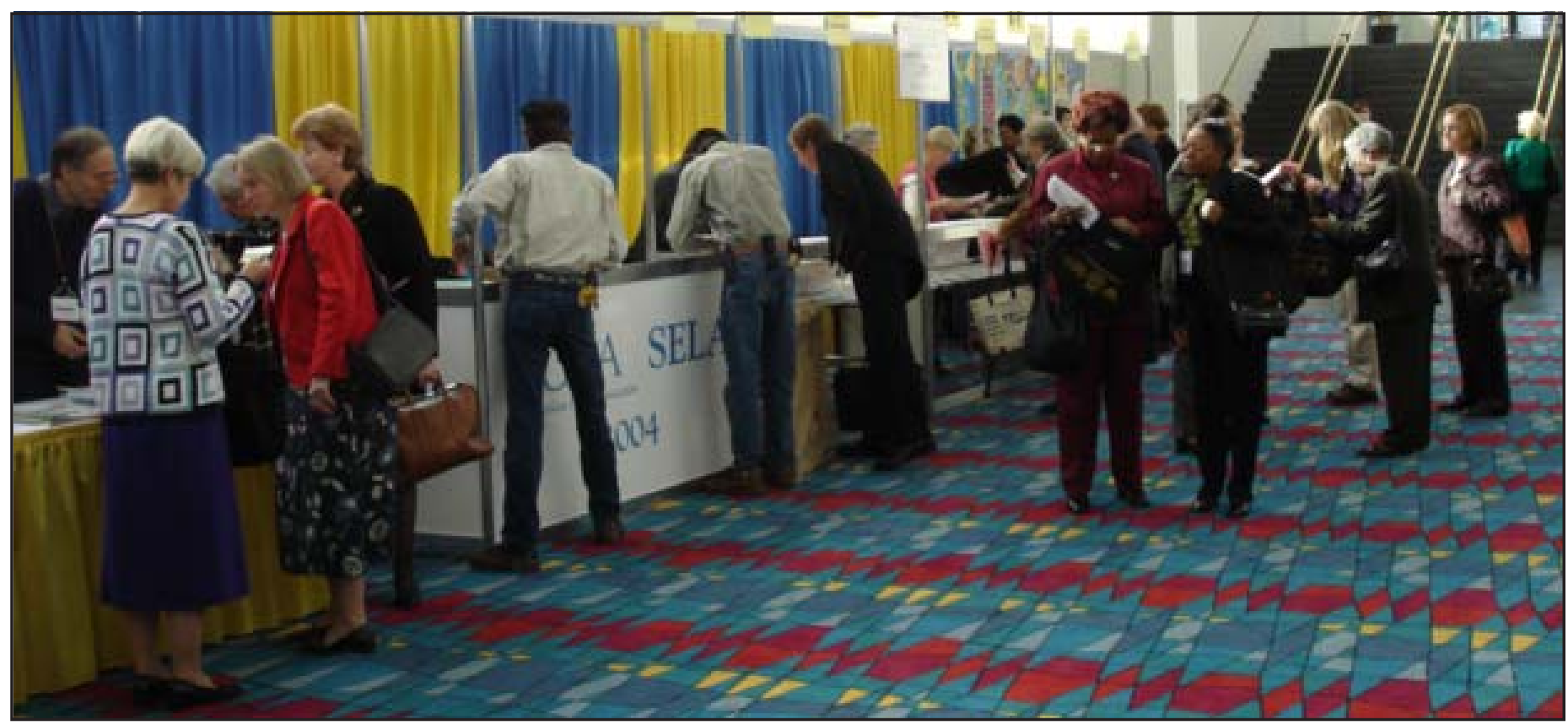

Attendees register for the conference in the lobby of the Charlotte Convention Center. Photo courtesy of Diane Kester. 
ing Impressions: Getting the Word out Effectively," with Linda Belans, host of two public radio programs and contributing writer for the Raleigh News \& Observer. Also, on Thursday, 10:45-11:45 a.m., LAMS sponsored "Staff Training-Is It What They Need?," with Michelle Hayslett and Raye Oldham (SLNC), Julie Goyette (High Point Public Library), Beth Hayden (Johnston Community College), and Georgia Williams (Chowan College).

On Friday, November 12, noon-1:30 p.m., the LAMS Personnel and Staff Development Interest Group sponsored a luncheon meeting, "We the People: The Heart of Our Business."

\section{Literacy Roundtable}

The NCLA Literacy Roundtable sponsored "Finding Quality Literacy Information Online" on Wednesday, November 10, 2:30-3:30 p.m., featuring Ralph Kaplan and Mary Siedow (National Institute for Literacy). On Thursday, November 11, 9:30-10:30 p.m., the Literacy Roundtable presented "A Splendid Combination: Literacy and Libraries," which highlighted a variety of library-based literacy programs, services, and initiatives.

\section{Movie}

On Thursday evening, November 11, 10:00 p.m., in the Francis Auditorium of the PLCMA, conference attendees were treated to a showing of the 1956 movie Desk Set, with Katharine Hepburn as a librarian who triumphs over efficiency expert Spencer Tracy's gigantic computer designed to displace her.

\section{NC LIVE}

NC LIVE presented "NC LIVE: Open Forum and Update," on Thursday, November 11, 4:15-5:15 p.m., with Ralph Kaplan, Scott Ross, and Leslie Van Deusen.

\section{NCLA Centennial Conference Committee}

On Thursday, November 11, 4:15-5:15 p.m., the Centennial Conference Committee, sponsored "Dr. Louis Round Wilson: Library Legend," with Robert Martin (Institute of Museum and Library Services). Martin discusses Wilson's service to the library profession as a founder and the first secretary/ treasurer of NCLA and his involvement in the founding of SELA. On Friday, November 12, 2:00-3:15 p.m., the NCLA Centennial Conference Committee sponsored "Pay-Per-View: Providing Access to Journals the Library Can't Afford," with Beth Bernhardt (UNCG).

\section{NCLA Centennial Conference History Committee}

On Wednesday, November 10, 3:45-5:00 p.m., Kevin Cherry, Chair of the Centennial Conference History Committee, presented "NCLA: The First Hundred years," "a hop, skip, and a jump over the past 100 years of library history in North Carolina."

On Thursday, November 11, 7:30-8:45 a.m., the NCLA Centennial Conference History Committee sponsored a breakfast meeting on "Documenting the American South: The First Ten Years," with Joe Hewitt, director emeritus, UNC-CH Libraries. Also, Thursday morning, 9:00-11:45 a.m., the Centennial Conference History Committee presented "Southern Librarians and Libraries Over Time and Distance: A Seminar." Seminar speakers and their topics included James Vinson Carmichael, Jr. (UNCG) on "The South as 'Other': Southern Female Librarians as Pawns and Brokers"; Louise S. Robbins (University of Wisconsin-Madison) on "Researching Ruth Brown: Racism and Retribution in a Southern Border State"; and Patrick Valentine (Wilson County Public Library) on "Small Select Library or Miserable Excuse: Antebellum Southern College Libraries."

The History Committee also sponsored two library history exhibits, the North Carolina Library Association Centennial Handbook, 1904-2004, a video scrapbook, a treasure hunt, a time capsule, and a series of "Centennial 
Moments," and kicked off a North Carolina library oral history project.

\section{NCLA Intellectual Freedom Committee}

On Friday, November 12, 2:00-3:15 p.m., the NCLA Intellectual Freedom Committee and the Library Instruction Roundtable co-sponsored "US PATRIOT Act Revisited," with Anne Klinefelter (UNC-CH) and Jim Kuhlman (UNC-Asheville).

\section{NCLA Leadership Institute}

On Wednesday, November 10, 2:30-3:30 p.m., Robert James (Duke University Medical Center Library) presented a program "Creating Library Leaders: The NCLA Leadership Institute."

\section{New Members Round Table}

On Friday, November 12, 10:30-11:45 a.m., the NCLA New Members Round Table presented "Secrets of Success: Keeping Up with Technology," with Beth Bernhardt (UNCG), Angela Ballard (NCSU Libraries), and Jody Risacher (Cumberland County Public Library).

\section{North Carolina Library Paraprofessional Association (NCLPA)}

On Wednesday, November 10, 2004, 2:30-3:30 p.m., the NCLA Library Paraprofessional Association sponsored a luncheon with author Bill Thompson, Columbus County native, who writes a monthly "Front Porch Stories" column in Our State Magazine. More than 60 people attended, giving Thompson rave reviews for his memorable and humorous North Carolina stories. Thompson read from his poetry, described interviews with potters, beauty queens, and fishermen, and even gave an a cappella rendering of an original

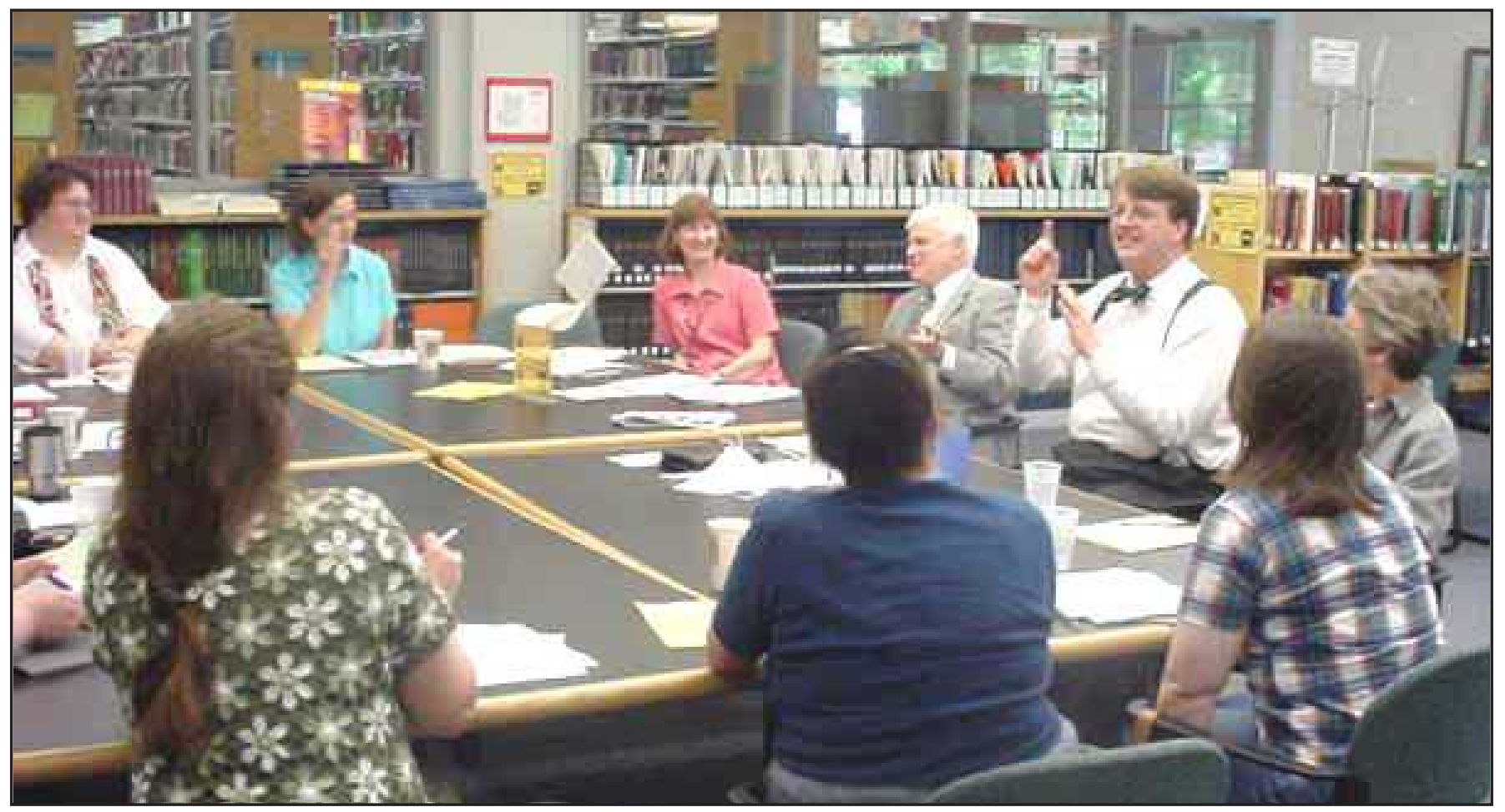

And then we will count our blessings, name them one by one. A portion of NCLA's Centennial Conference History Committee at work in the reading room of the Olivia Raney Local History Library (Wake County) on 5 April 2004, planning its activities for the conference. Around the table clockwise: Paula Brown (Gaston Lincoln Regional Library), Barb Gushrowski (University of North Carolina-Pembroke), Cheryl McLean (State Library of North Carolina), John Via (Forsyth County Public Library), Kevin Cherry (East Carolina University), Eileen McGrath (University of North Carolina at Chapel Hill), Dianne Johnson (School of Medicine, Wake Forest University), Georgia Williams (Chowan College), and Joan Sherif (Northwestern Regional Library). Photo courtesy of Patrick Valentine. 
song. Many of the attendees either brought or purchased copies of

Thompson's latest book Sweet Tea, Fried Chicken, and Lazy Dogs: Reflections on

North Carolina Life, which he autographed following the program.

Throughout the conference, the NCLPA also maintained an exhibit

illustrating its history and activities, including agendas and minutes from its

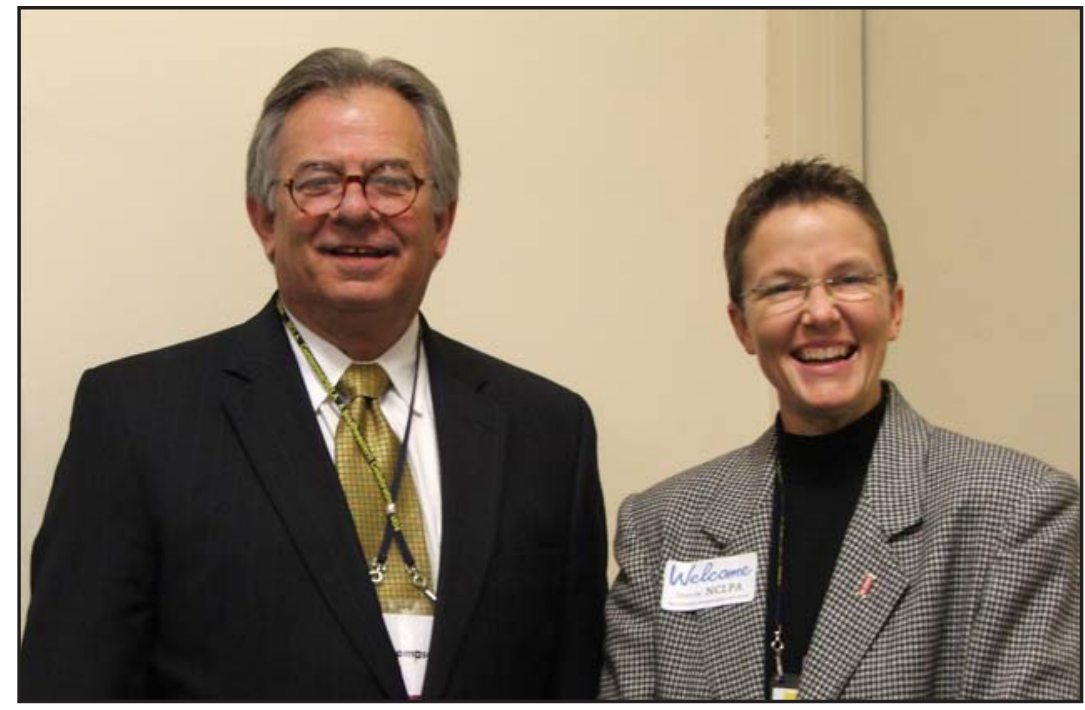

Bill Thompson, North Carolina author and speaker at the North Carolina Library Paraprofessional Association (NCLPA) program on Wednesday, November 10, 2:30-3:30 p.m., with Annis Barbee (North Carolina State University), NCLPA Chair. Photo courtesy of Jackie Frye. earliest business meetings, archived newsletters, and a variety of resolutions submitted to NCLA. Conference attendees who visited the exhibit learned of opportunities to participate in the NCLPA's work on behalf of library support staff. Opening the exhibit on Wednesday, November 10, North Carolina mystery writer Sarah Shaber signed and distributed copies of her books from the display table and awarded a hardback set of her mystery series as a door prize.

North Carolina Preservation Consortium On Thursday, November 11, 10:45-11:45 a.m., the North Carolina Preservation Consortium presented "Assessing Preservation Needs: A Self-Survey Guide," with Steve Dalton (Northeast Document Conservation Center (NEDCC)).

\section{Public Library Section (PLS)}

On Wednesday, November 10, 2004, 12:302:00 p.m., the NCLA Public Library Section sponsored a luncheon feature author Daniel Wallace, a resident of Chapel Hill, and author of three novels.

On Wednesday, 2:30-3:30 p.m., Warren Graham, PLCMC Security Manager, presented a program "How to Say "NO" to Customers: Security Issues." Concurrently, also 2:30-3:30 p.m., the PLS AV Committee sponsored Pat McGee (Tennessee Technological University), and a panel of North Carolina librarians, who presented "Is It Time to Turn the Battleship Around?: Lending Audiovisuals Through ILL," and the PLS Reference Committee presented "SmART Connections: Library and Museum Partnership," featuring Susan Perry (Mint Museum, Charlotte), Helen Blowers (PLCMC), and a panel. Also, on Wednesday, 3:45-5:00 p.m., the PLS Technical Services Committee presented "RFID Technology: Demonstration and Discussion" with Phillip Whitford, Braswell Memorial Library.

On Thursday, November 11, 2004, 10:45-11:45 a.m., PLS sponsored "ImaginOn: Charlotte's New Children's Theatre and Library" with Melanie Huggins (PLCMC), and Bruce LaRowe (Children's Theatre of Charlotte). Also, on Thursday, 4:15-5:15 p.m. the PLS Reference Committee presented "Teens: Getting It Right!" featuring Melanie Huggins, Tony Tallent, and Mercede Walker (PLCMC), Mary Alice Katon (THINK College and Career Center, communities in Schools, Charlotte), and Susan Harden (Library Initiative for Youth in Business, PLCMC). During the same time period on Thursday afternoon, the PLS Genealogy Committee sponsored "Genealogical Triage" with Arthur Erickson (Greensboro Public Library).

On Friday, November 12, 10:30-11:45 a.m., the PLS sponsored "U.S. Geological Survey: Products, Services, and Databases."

\section{Public Library Trustees Association}

The NCLA Public Library Trustees Association sponsored "Getting What You Want: Working with Elected Officials," featuring Ken Eudy, CEO of Capstrat, on Thursday, November 11, 9:30-11:00 a.m. 


\section{Receptions}

The Early Arrivals Reception was held Tuesday, 7:30-10:00 p.m. at the Westin Charlotte Hotel. On Wednesday evening, November 10, 2004, 5:00-6:00 p.m. the Vendors Reception was held in the Exhibits Hall of the Charlotte Convention Center. The NCLA and SELA New Members Round Tables jointly sponsored an orientation meeting and reception on Wednesday evening, 6:00-7:00 p.m., and the Public Library of Charlotte and Mecklenburg County sponsored a reception, 8:15-10:00 p.m., at its main library, featuring an exhibit on NCLA's first conference held in Charlotte in 1904.

On Thursday evening, 5:30-7:30 p.m., the Cooperative Library Schools Reception welcomed alumni for a reunion of Southeastern library schools. The All Conference Reception was held at 10:00 p.m. at the Levine Museum of the New South.

\section{Reference and Adult Services Section (RASS)}

On Thursday, November 11, 2004, 10:45-11:45 a.m., Katherine Dexter Willis (NCSU Libraries) presented "Learning for Life: Library Services and Nontraditional Students," which described their specialized needs and presented strategies to assist them with library research, including remote use of online resources.

On Wednesday, November 10, 2004, from 2:30 to 3:30 p.m., Duncan Smith, product manager of Novelist, presented a two-part program entitled "Readers' Advisory Renaissance." In part 1, he described the process of helping readers find new books by asking them to describe a book they had recently read and enjoyed. From 3:45 to 5:00 p.m. on Wednesday, Part 2 of the program was a demonstration of the online reader's advisory tool, NoveList, with suggestions for using it effectively and creatively. These programs were sponsored jointly by the NCLA and SELA Reference and Adult Services Sections.

On Thursday, November 11, 9:30-11:00 a.m., NCLA RASS and SELA RASS presented "Bridging the Gap: Mentoring in Academic \& Public Libraries," with Kate Hickey (Elon University), Laura Davidson (Meredith College), and Julie Walker (Georgia Public Information Network for Electronic Services (PINES) Program).

The RASS luncheon on Friday, November 12, noon-1:30 p.m., featured Bob Inman, award-winning novelist, screenwriter, and playwright, who described the background of some of the settings and stories in his writings.

\section{REFORMA (Carolina Chapter)}

On Friday, November 12, 10:30-11:45 a.m., the new Carolina Chapter of REFORMA presented "Magnifico!: Organizing and Implementing Children's Day/Book," featuring Robin Imperial (Wake County Public Libraries), Tom Kenlan (formerly of Wren Memorial Library), Denise Nelson and Irania Patterson (PLCMC), Sandra Rodriquez (El Pueblo, Inc.), Jon Sundell (Forsyth County Public Library), and Kelley Villota (Asheville-Buncombe Public Library), and Tom Kenlan.

\section{Resources and Technical Services Section (RTSS)}

On Thursday, November 11, 10:45-11:45 a.m., Elizabeth Cramer (Appalachian State University) presented "Graphic Novels," a program sponsored by the NCLA RTSS. Speaking to an interested and enthusiastic standing-roomonly crowd, Cramer discussed the development of the graphic novel format, introduced vocabulary and definitions, and presented collection development tips: how to select graphic novels for library collections, how to judge their quality, and how to provide access to them.

On Friday, November 12, 10:30-11:45 a.m., RTSS sponsored a panel discussion, "One Record or Many? Cataloging Electronic and Print Resources." The four speakers represented library technical and public services at three University of North Carolina institutions: Mary Jane Conger and 
Audrey Fenner (UNCG), Sue Ann Cody (UNCW), and Patti Easley (UNCC). The panelists presented examples of the single and multiple record approaches to cataloging electronic and print resources, and described the impact of cataloging decisions on OPAC displays and ease of access for users.

Concurrently, also 10:30-11:45 a.m., on Friday, a panel discussion "State Procurement and Purchasing Issues" was co-sponsored by RTSS and the NCLA CJCLS, with Debbie Luck (Randolph Community College), Irene Laube (Durham Technical Community College), and Ann-Marie Breaux (Yankee Book Peddler Library Services, a Baker \& Taylor Company), on the State of North Carolina's "e-procurement" system.

\section{Round Table for Ethnic Minority Concerns (REMCo)}

The NCLA REMCo sponsored "Increasing Multicultural Awareness in a Florida Elementary School," featuring Linda Alexander (School of Library and Information Science, University of South Florida) on Wednesday, November 10, 3:45-5:00 p.m. This program was co-sponsored with the NCLA CSS.

On Friday, November 12, noon-1:30 p.m., REMCo and the SELA African American Issues Roundtable co-sponsored a luncheon meeting featuring Raymond A. Winbush (Institute for Urban Research at Morgan State University, Baltimore), and the author of numerous articles on the politics of Afrocentricity and the resistance it encounters among scholars.

\section{Round Table on Special Collections}

The NCLA Round Table on Special Collections sponsored three programs. ECU's Carroll Varner facilitated a panel entitled "Collaborative Digital Projects: The NC ECHO Experience" on Thursday, November 11, 2004, 4:15 to 5:15 p.m. Presenters were: Kim Cumber on "NC ECHO: A Program Built on Collaboration"; Pat Ryckman, Charlotte Latin School (formerly with UNCC), on UNCC's "New South Voices: An NC ECHO Collaborative Digital Project"; and Diana Williams on ECU's "NC ECHO Heritage Partners."

On Friday, November 12, 2004, 10:30 to 11:45 p.m., Helen Wykle (UNCA) spoke on "Representing the Under-Represented in Local History Collections: Processes, Problems, and Possibilities." This presentation was cosponsored by the NCLA REMCo. On Friday, November 12, 2:00-3:15 p.m., Libby Chenault (UNC-CH) discussed "Are We Keeping Our History?," based on a 1997 exhibition at UNC-CH, "The Invisible Process: Ingenuity and Cooperation in Finding Women's Lives."

\section{Round Table on the Status of Women in Librarianship (RTSWL)} On Wednesday, November 10, 2004, 12:30-2:00 p.m., the NCLA RTSWL sponsored a "Hissy Fit Luncheon," with Kathy Trocheck, AKA Mary Kay Andrews, a former reporter for the Atlanta Journal-Constitution, and now a mystery writer who lives in Raleigh.

On Thursday, November 11, at the Presidents' Luncheon, Linda Stone (Dean, Central Piedmont Community College) was presented the Marilyn L. Miller Award for Professional Commitment by the RTSWL.

\section{Southeastern Library Association (SELA)}

On Wednesday, November 10, 2:30-3:30 p.m., SELA presented "Seeding the Vision: A Minority Librarian Residency Program," with Jill Keally and Thura Mack (University of Tennessee-Knoxville). Also, on Wednesday, 2:30-3:30 p.m., SELA presented "New ACRL Academic Library Standards," with Bill Nelson (Augusta State University).

On Thursday, November 11, 9:30-10:30 a.m., SELA presented "OCLC Connexion for Cataloging," with Rose Davis (Western Kentucky University). On Thursday, 9:30-11:00 a.m., SELA presented "Information Commons: An Emerging Trend in Libraries," with Russ Bailey and Barbara Tierney (UNCC), David S. Goble (Central Piedmont Community College), Rich Rosenthal 
(PLCMC), Pat Ryckman (Charlotte Latin School), and Crit Stuart (Georgia Institute of Technology). On Thursday, 10:45-11:45 a.m., SELA sponsored "Growing Georgia PINES: Georgia's Statewide Library Card," with Georgia Deputy State Librarian David Singleton and PINES Program Director Julie Walker. On Thursday afternoon, 4:15-5:15 p.m., SELA sponsored "Incorporating an Automatic Retrieval System in an Academic Library's Expansion," featuring Georgia Southern University's library expansion/renovation project. Concurrently, 4:15-5:15 p.m., SELA sponsored "If You Pay Them, They will Come: Information Literacy Workshops for Faculty," with Jennifer Little and Cole Jacques (University of South Carolina-Aiken).

On Friday, November 12, 2:00-3:15 p.m., SELA sponsored "New Libraries in the Southeast: A Showcase," with Beverly James (Greenville (SC) Public Library). Concurrently, SELA presented "Staff Retreats: Who Needs 'Em?," with Carol Nutter and Elsie Pritchard (Morehead State University (KY)).

\section{SELA African American Issues Round Table}

On Thursday, November 11, 7:30-8:45 a.m., the SELA African American issues Round Table sponsored a breakfast meeting in honor of author Zelda

Lockhart, a native of Mississippi, who now makes her home in Hillsborough.

\section{SELA Circulation and Reserves Roundtable}

On Friday, November 12, 2:00-3:15 p.m., the SELA Circulation and Reserves Roundtable presented "Library Security: Pointers for Creating a Successful, Sustainable Security Program," with Crit Stuart (Georgia Institute of Technology) and Fred Smith (Georgia Southern University).

\section{SELA Continuing Education Committee}

On Wednesday, November 10, 3:45-5:00 p.m., the SELA Continuing Education Committee presented "Planning a Statewide Library Conference," including discussion of an interactive database.

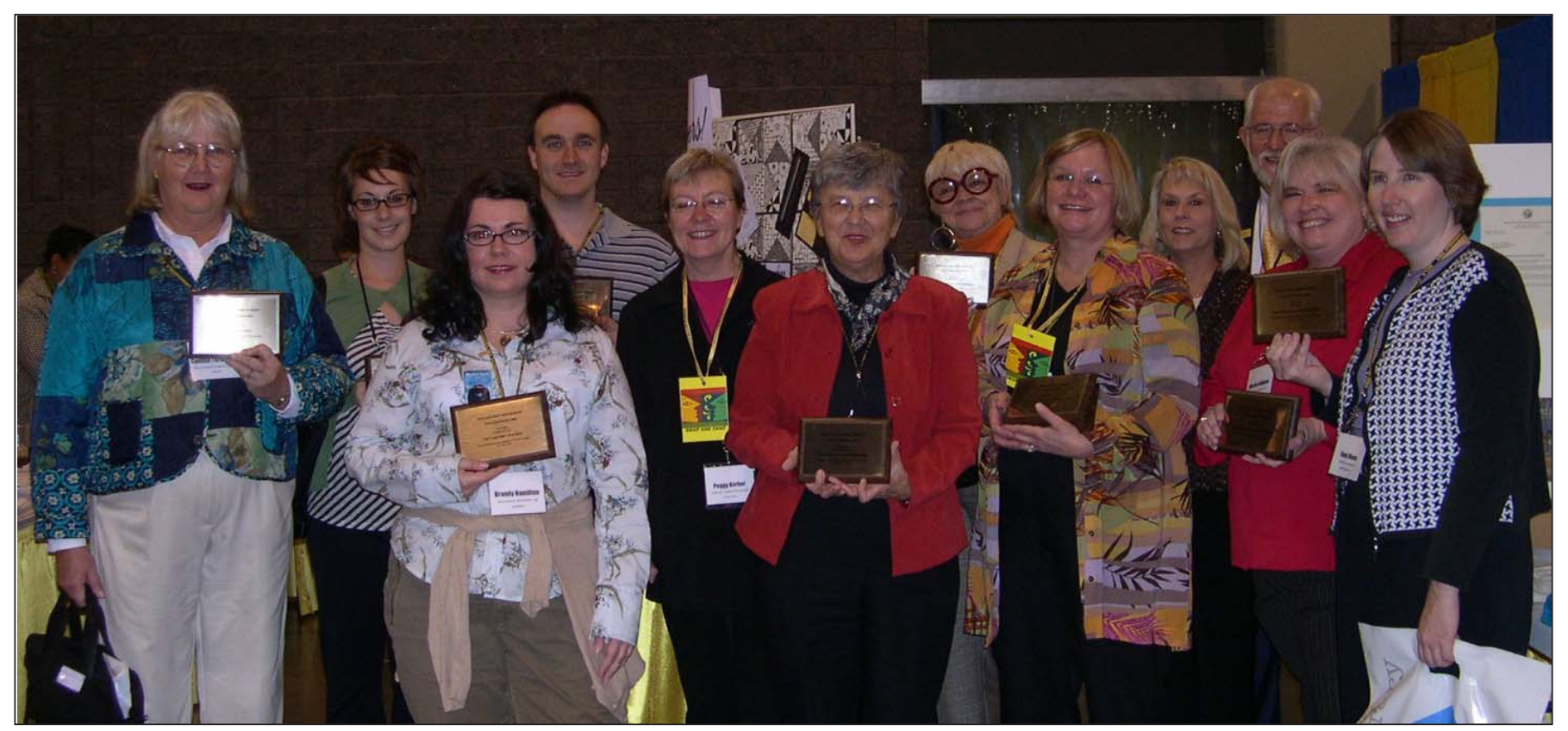

Winners of the NCLA/SELA PR event (left to right): Cynthia Terwilliger, Polk County Public Library; Amy Gresko, Meredith College Library; Brandy Hamilton, Wake County Public Libraries; Russell Godfrey, Sequoyah Regional Library (GA); Peggy Barber (Library Communications Strategies, Inc.); Sonia Coffin, Central Piedmont Community College (CPCC); Carol Walters, Sandhill Regional Libraries; Susan Parrish, Cumberland County Public Library and Information Center; Laura Purcell (University of Tennessee); David Goble (CPCC); Marcia Addison (CPCC); and Gena Moore (CPCC). Photo courtesy of Sonia Coffin. 


\section{SELA Interstate Cooperation Committee}

On Thursday, November 11, 9:30-11:00 a.m., the SELA Interstate Cooperation Committee sponsored "Collaboration for Digitization Projects," with Toby Graham (Digital Library of Georgia).

\section{SELA Library Instruction Roundtable}

On Wednesday, November 10, 3:45-5:00 p.m., the SELA Library Instruction Roundtable presented "The Bibliographic Instruction Classroom Course: Instructors' Perspectives," with Jennie Hunt (Greensboro College); Janet Ferguson (UNCA); Linda Colding (University of Central Florida); and Michael Wilson (Shorter College (GA)). On Friday, November 12, 2:00-3:15 p.m., the SELA Library Instruction Roundtable presented "Tips for New Bibliographic Instruction Coordinators."

\section{SELA Outstanding Author Award Committee}

On Wednesday, November 10, 12:15-2:15 p.m., the SELA Outstanding Author Award Committee sponsored a SELA Awards and Business Luncheon at which two authors were recognized: Sena Jeter Naslund and Louis D. Rubin, Jr.

\section{SELA Public Library Section}

On Thursday, November 11, 4:15-5:15 p.m., the SELA Public Library Section presented "Marketing on a Shoestring," with Kathleen Imhoff (Lexington (KY)

Public Library). Concurrently, the SELA Public Library Section also sponsored "Academic and Public Libraries partner for Progress," with Lisa Rice (Bowling Green Public Library) and Jayne Pelaski (Western Kentucky University).

Right: Bea Kovacs (University of North CarolinaGreensboro) with three of her library science students: (Left to right) June Powers (University of North Carolina-Pembroke), Allyson Davis (State University of West Georgia), and Cole Jacques (University of South Carolina-Aiken).
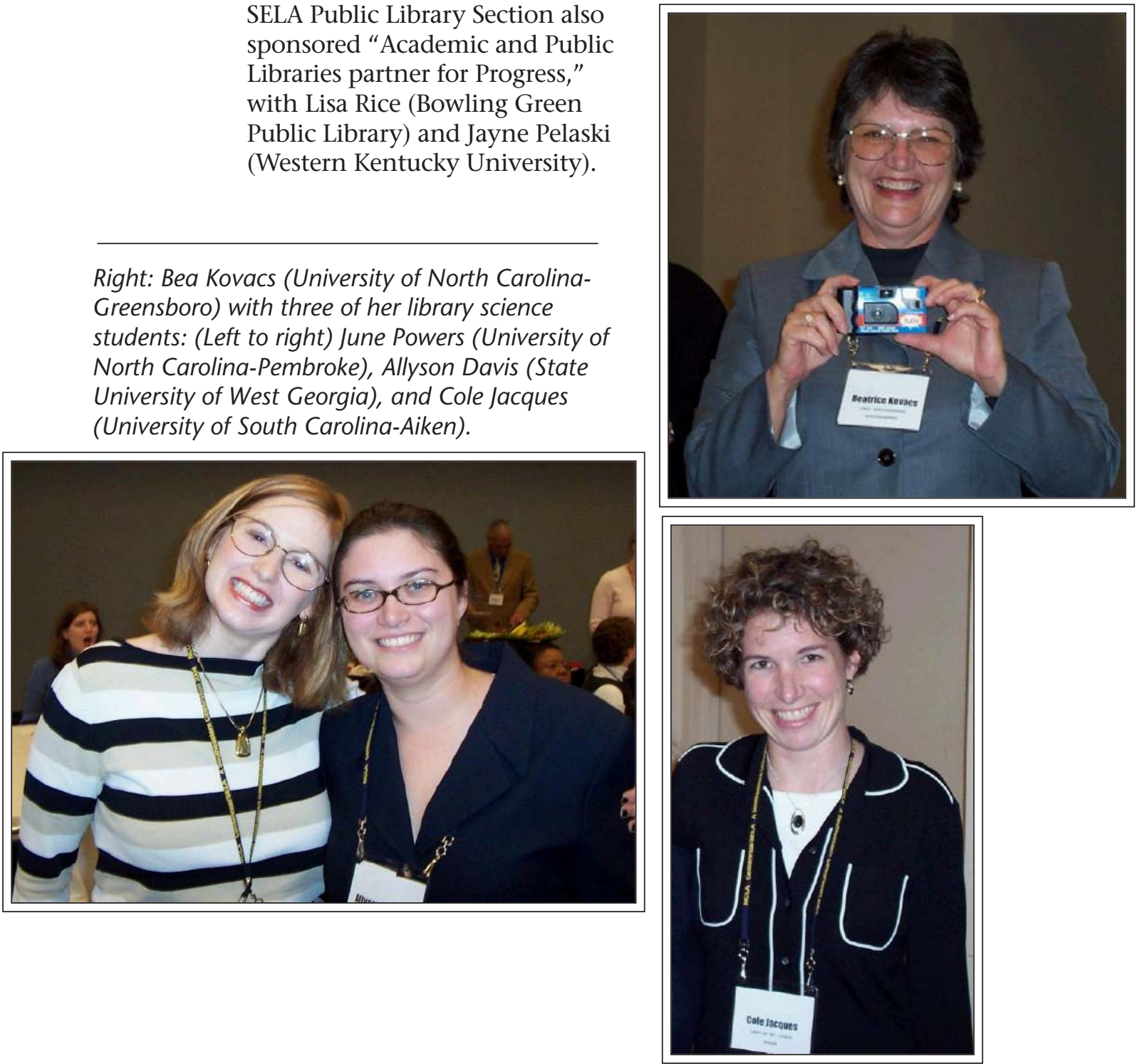
SELA University and College Library Section

On Wednesday, November 10, 3:45-5:00 p.m., the SELA University \& College Library Section presented "Decline of the Monograph: Restoring Balance," with Milton T. Wolf (University of Central Florida) and Suzy Szasz Palmer (University of Louisville). On Friday, November 12, 10:30-11:45 p.m., the SELA University and College Library Section sponsored "New Voices: Ideas from new Librarians," with Marcia Sterrett Kalayjia and Judy Freshwater Polak (Kanawha County (WV) Public Library), Beth Weixler (North Virginia Community College, Alexandria), Pamela Aban and Brett Spencer (University of Alabama-Tuscaloosa), Amia Baker (Vanderbilt University), Richard A. Stoddard (Georgia Southwestern State University), Sheri Helt and Adrienne Lee (University of Southern Mississippi), and Bryan Tronstad (University of Wyoming).

\section{State Library of North Carolina (SLNC) (including The Center for the Book)}

The State Library of North Carolina sponsored "MedlinePlus and NC Health Info: A Healthy Combination," with Becky Hebert (National Network of Libraries of Medicine) and Christie Silbajoris (NC Health Info), on Thursday, November 11, 9:30-10:30 a.m. The Center for the Book of the SLNC sponsored "Let's Talk About It": Unknown Worlds: Identities in the South," on Thursday, November 11, 9:30-11:00 a.m. Also, on Thursday, 10:45-11:45 a.m., the SLNC presented "Virtual Reference Projects in the Southeast." On Thursday, 4:15-5:15 p.m., the SLNC and NCLA sponsored "Poetry Spoken Here: Poetry Programs and Resources for Libraries," with Steve Sumerford and Gale Greenlee, Greensboro Public Library.

On Friday, November 12, 2:00-3:15 p.m., the SLNC sponsored "Rotary Readers: Union County Library's Partnership with the Rotary Club," with Beth Medlin (Union County Public Library) and Union West Rotary Club members.

Hundreds of conference attendees filled their bags with publicity materials, chatted with fellow librarians, and shared ideas with public relations professionals. The three Swap and Chat sessions were held from 1:00 to 2:15 p.m. on Wednesday, November 10, 2004; 3:30-5:00 p.m. on Thursday, November 11; and 9:00-10:15 a.m. on Friday, November 12. The planning group worked tirelessly on Tuesday to organize the sample publicity materials sent from libraries along the east coast. Dorothy Hodder, Susan Parrish, Kim Webb, Carol Walters, Lisa Sheffield and Dale Cousins hauled boxes, set up the displays, and welcomed conference attendee. During the Swap and Chat sessions, participants took the opportunity to discuss marketing ideas with Public Relations specialist Peggy Barber.

The Best of Show winners were recognized in an awards ceremony on Wednesday. Librarians entered their best public relations materials in the competition and winners were selected based on content, originality, design, format and effectiveness. Entries were received from North Carolina, South Carolina, Tennessee, and Georgia.

\section{Technology and Trends Roundtable (TNT Roundtable)}

The NCLA TNT Roundtable sponsored "'The Kids Are all Right': The Millennial Generation," on Wednesday, November 10, 3:45-5:00 p.m., featuring Steve Abram, President of the Canadian Library Association, and Vice President for Innovation, Sirsi Cooperation. On Thursday, November 11, 9:30-10:30 a.m., the TNT Roundtable presented "Counting Uses and Using Counts: Evaluating Usage of Online Resources," with Beth Bernhardt (UNCG), Barbara Gushrowski and Cindy Saylor (UNCP), and Andrea Eastman (UNC Teaching and Learning with Technology Collaborative). 